Short Communication

\title{
Appropriate Number of Sex Pheromone Trap for Monitoring Spodoptera exigua Hubner (Lepidoptera: Noctuidae) Moths on Shallot Field
}

\author{
Dian Lestari $^{1) *}$, F. X. Wagiman ${ }^{1)}$, \& Edhi Martono ${ }^{1)}$ \\ ${ }^{1)}$ Department of Plant Protection, Faculty of Agriculture, Universitas Gadjah Mada \\ Jln. Flora No. 1, Bulaksumur, Sleman, Yogyakarta 55281 Indonesia \\ *Corresponding author.E-mail: dilesta.dl90@gmail.com
}

Received April 3, 2017; revised June 15, 2017; accepted November 27, 2017

\begin{abstract}
The research was carried out to determine the appropriate number of sex pheromone traps for monitoring the Spodoptera exigua moths in shallot crop which was grown in Yogyakarta Special Territory, Bantul Regency (Samas). This research was conducted in August until September 2016. Sex pheromone trap was arranged on shallot aged 3 weeks after planting. Sex pheromone trap with hexadecenat tetra asetat ingredients was placed on sticky yellow trap. This research used RCBD experimental design with single factor experiment namely the number of trap i.e. $3,5,6,8$ units $/ 2.000 \mathrm{~m}^{2}$ with sex pheromone, and three traps without sex pheromone as control. Each treatment was repeated 5 times so 125 samples of experiments were obtained. Observation was made by counting the number of moths caught in sex pheromone trap. The result of observation was analysed with analysis of variance (ANOVA) and DMRT $\alpha$ $5.0 \%$. The results show that the appropriate number of trap to monitor the pest infestation was 3 units $/ 2.000 \mathrm{~m}^{2}$.
\end{abstract}

Keywords: sex pheromone trap; shallot; Spodoptera exigua

\section{INTRODUCTION}

Indonesia is one of countries who love flavor taste so much. One of herb that must be in dish is shallot. Besides being used as a flavor, shallot also has high economic and nutrient value. Shallot has big role in life through of people especially to farmers, that's way most of farmers were attracted to cultivation a shallot. One of the centers of shallots production is Bantul, Yogyakarta. Within a year there are three planting seasons i.e. July to October, November to February, and March to June. Pest problem is one of major constraint for achieving higher production in shallot cultivation. Febrianasari (2014) stated that Spodoptera exigua Hubner (Lepidoptera: Noctuidae) is one of important pest that can be obstacle the farmers from getting the maximum production (20 ton/ha) and good quality.

Spodoptera exigua has attacked shallot throughout the year. Larval stage of S. exigua has high feeding activity by eating all a part of leaves. Leaves have attacked by larva of $S$. exigua seem like transparant and then leaves look like droop and dry up (Kalshoven, 1981). Thus condition can make high losses for production and it will be worst when populations of
S. exigua was increasing (Mau \& Kessing, 2007; Khasanah et al., 2014). The $S$. exigua larvae attack shallot during vegetative growth stage and can cause yield loss of about $57-100 \%$ (Putrasamedja et al., 2012). According to Nurjanani and Ramlan (2008), variation of demage of S. exigua attack start from $3.89-100 \%$, it depended of management of shallot cultivation. Heavy attack can caused high losses until $100 \%$, if there was no controlling of pest attack and it can caused crop failure and production of shallot should be come down (Haryati \& Nurawan, 2009; Khasanah et al., 2014).

Commonly, farmers used synthetic insecticides to minimize losses and controlling S. exigua. Farmers were preferring to used synthetic insecticides because they are readily available, highly promoted, inexpensive, easy to apply and quick acting (Islam, 2012). Most of farmer used insecticides as intensively, and the pests are becoming resistant to almost all chemical pesticide as the frequency of spraying is gradually increasing while their efficacy is gradually decreasing. Wagiman et al. (2003) stated that the use of chemical insecticides is feared to leave residues on the shallot bulbs, and if the shallot bulbs were consumed in fresh condition it will have impact on 
consumer health. There are many alternative approaches to control insect pest such as using pheromone technology like sex pheromone traps.

In most insects, pheromones are produced by glandular epidermal cells concentrated in discrete areas beneath the cuticle, but in some species, gland cells are scattered through the epidermis of different parts of the body. For click beetles, the male attractant pheromone is produced by female pheromone glands located at the last abdominal segment (Reddy \& Tangtrakulwanich, 2014). According to Wyatt (2010), pheromones are chemical signals that are used to communicate between species of insects. Sex pheromones are specific chemicals released by females into the air to attract specific males for mating. Males follow the sex pheromone upwind to locate and mate with the female (Kong et al., 2014). Pheromone traps, which attract male $S$. exigua moths, can be an indicator of moth activity in the area. However, trap catch numbers may not necessarily relate directly to numbers of larvae in a field

The utilization of sex pheromone to control insect pest is one of advance technology. The sex pheromone is one method to control insect pests for support food security. In other to know the ability of sex pheromone to trap insect the monitoring of insect using sex pheromone is needed. Sex pheromone can be used as a monitoring tool of pest population in the field and for mass capture of male insects. The sex pheromone disturbs the mating activities of insects so they will be fail to mate, as a result the produced eggs will not be fertilizing and hatching. The further impact is that population of $S$. exigua and damage rates will be reduced. The pheromone traps is environmentally sound due to not toxic. The sex pheromone was more widely used than the other pheromones as sex pheromones are more easily obtained (Martono, 1997). The pheromone traps can be used as monitoring and early detection of $S$. exigua infestation. A sex pheromone trap contains tetra hexadecenat asetat as active ingredients that are attached to yellow sticky plastic sheet. Number of sex pheromone trap per hectare may determine the effectiveness to trap the $S$. exigua male moths. This study was aimed to determine the appropriate number of sex pheromone traps for monitoring the $S$. exigua moths.

\section{MATERIALS AND METHODS}

The research was conducted from August until September 2016 in the shallot grown in Sanden, Bantul, Yogyakarta. The sex pheromone trap was obtained from Agritek Tani Indonesia Ltd. The trap is composed of a yellow sticky plastic sheet and the sex pheromone cointaining hexadecenat tetra acetat. The treated area was selected at shallot area with infestation intensity rate of $S$. exigua more than $20 \%$. Field sampling conducted on shallot age of 3 weeks after planting.

This research is using RCBD experimental design with single factor experiment namely number of trap i.e. $3,5,6,8$ units $/ 2,000 \mathrm{~m}^{2}$ with sex pheromone, and control (3 traps without sex pheromone) with five replications. Experimental plot was a shallot plantation of about $2.000 \mathrm{~m}^{2}$ or $50 \times 40 \mathrm{~m}$. Each block had a set of treatments that consisted of five treatments including control so that the total trial plot per block was 1 hectare and sum of sample was 125 unit. Inter plots were separated by difference distance depend on number of trap. Distance among 3 traps were $12.5 \mathrm{~m}, 5$ traps were $8.3 \mathrm{~m}, 6$ traps were 7.14 and 8 traps were $6.25 \mathrm{~m}$. Distances among blocks were $200 \mathrm{~m}$ and among plots were more than $50 \mathrm{~m}$. Distance among block was separated with other plant, street and houses. According to Kardinan (2003), metil eugenol was attractant compound on mating process (sex pheromone) of fruit flies, the potency of this compounds can attract insect for come around $20-100 \mathrm{~m}$.

The observation parameter was the number of $S$. exigua moths caught. The observation was conducted at every 5 days since trap installation until the shallot ready to harvest. Sex pheromone trap was effective to catch $S$. exigua moths if the number of caught moths on treated plot was significantly than control treatment, because control treatment is yellow sticky trap without sex pheromone. The effectiveness of the sex pheromone trap was determined refering to based on the results of analysis of variance (ANOVA) and DMRT $\infty 5.0 \%$. Meanwhile the appropriate number trap was determined according to the significant difference amongst treatment. 


\section{RESULTS AND DISCUSSIONS}

The result of the number of moths caught for six times from August until September in Sanden, Bantul Regency showed that average cumulative number of $S$. exigua moths highly significant difference (F $<0.0001$ ) amongst treatments including control. Control (yellow sticky trap without sex pheromone) has significant difference with other treatment $(3,5$, 6 , and 8 trap with sex pheromone). There's no moths were trapped on control treatments, while in others treatments average number of moths were 9 until 36 moths/trap (Figure 1). It was mean sticky yellow trap with sex pheromone more effective to catch moth than sticky yellow trap without sex pheromone. Eight traps can catch until 36 moths higher than three traps of nine moths caught. Differences density of sex pheromone can effect for number of moths trapped.

The noctuid moths are active at night especially at full moon (Sukarsono, 2016; personal communication). At the night, the chemical sense was more functionate to detected synthetic pheromone than visual sense to detected color of trap (Santi \& Sumaryo, 2008). There was no moth in control treatment but it was in other treatment, it was mean that at night the noctuid insect may not distinguish the color on trap (sticky yellow trap) but it was attracted on sex pheromone. According to Haryati et al., (2009) Sex pheromone of $S$. exigua was produced by female moth especially at night to attracted male moth to come $\mathrm{n}$ get mate. So can be sure that male moth was trapped in sticky yellow trap.

Average cumulative total number of the moth for these observations was used as a basic for determining the appropriate number of sex pheromone trap per hectare. Trap Installation at several days before planting can be useful for early pest detection. Pheromone with the active ingredient of tetra acetic hexadecenat is specific for male moths. If the trap was installed at beginning of plant, most of male moths were died while stuck on sticky yellow trap and the egg will not be fertilizing and hatching.

The average cumulative number of moth caught in the trap density of 3, 5, 6 and 3 traps without sex pheromone as control units $/ 2000 \mathrm{~m}^{2}$ were significantly lower than 8 units $/ 2000 \mathrm{~m}^{2}$ (Figure 1). The appropriate number of trap to monitor the pest infestation was 3 traps units $/ 2.000 \mathrm{~m}^{2}$ with sex pheromone, it can be appropiate number for monitoring because with a few trap can catch moth $S$. exigua. Pheromone traps can be useful as a tool for early detection and monitoring of the pest infestation. The egg of $S$. exigua was discovered when shallots are in 4-7 DAP of age (Sutarya, 1996). If the trap was installed at a week before planting and it caught $S$. exigua moths, it means that the trap can be used to prevent the pest infestation as early as possible.

In addition the sex pheromone traps are useful for early detection and monitoring of pest infestation and also it has the potential to control the pest by

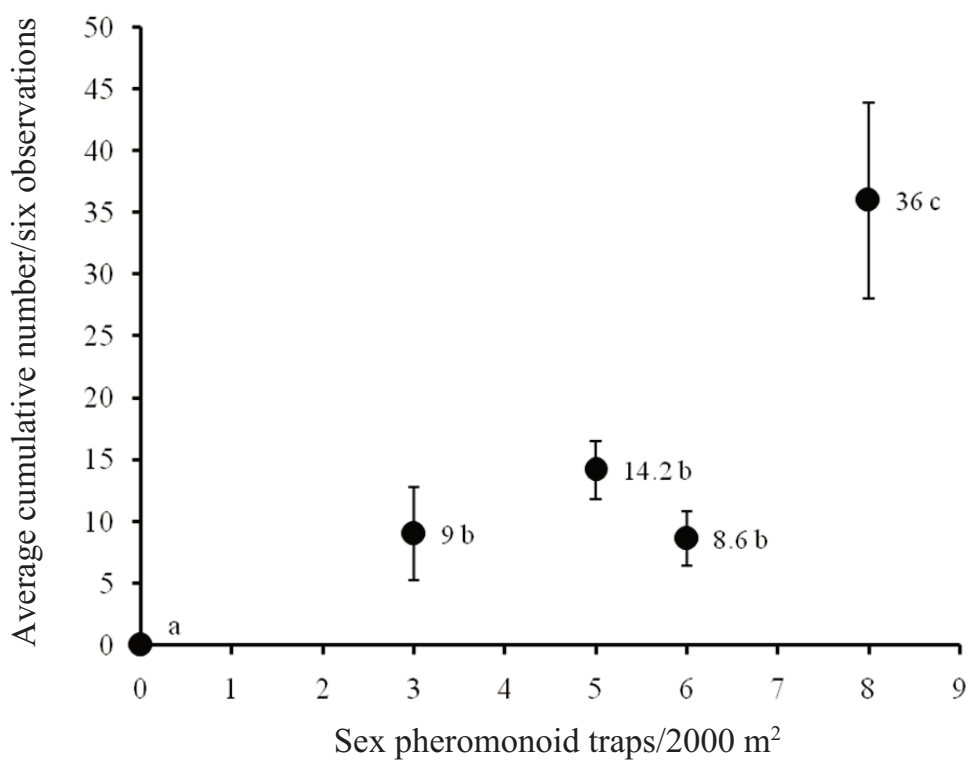

Figure 1. Average cumulative number of Spodoptera exigua moths 
the way of trap and kill. Haryati and Nurawan (2009), stated that the sex pheromono has opportunity to be developed in shallots production centers, particularly in endemic areas of the shallot pest. The most important thing of monitoring is to determine if they are present in area or to determine if enough insect are present to warrant a costly treatment.

\section{CONCLUSION}

The sex pheromone trap with the active ingredient of tetra hexadecenat tetra asetat which attached on the yellow sticky sheet was effectively to capture $S$. exigua moths. The appropriate number of trap to monitor the pest infestation was 3 units $/ 2.000 \mathrm{~m}^{2}$.

\section{ACKNOWLEDGEMENT}

Thanks and highly appreciation to Agritek Tani Indonesia Ltd. which had facilitated the study, shallot farmers in Sanden District, Bantul Regency who had allowed their shallot field for the study, as well as to all parties for their supports.

\section{LITERATURE CITED}

Febrianasari, R., H. Tarno, \& A. Afandhi. 2014. Efektivitas Klorantraniliprol dan Flubendiamid pada Ulat Bawang Merah (Spodoptera exigua Hubner) (Lepidoptera: Noctuidae). Jurnal Hama dan Penyakit Tumbuhan 2: 103-109.

Haryati, Y. \& A. Nurawan. 2009. Peluang Pengembangan Feromon Seks dalam Pengendalian Hama Ulat Bawang (Spodoptera exigua) pada Bawang Merah. Jurnal Litbang Pertanian 28: 72-77.

Islam, M.A. 2012. Pheromone Use for Insect Control: Present Status and Prospect in Bangladesh. International Journal of Agricultural Research, Innovation and Technology 2: 47-55.

Kalshoven, L.G.E. 1981. The Pest of Crops in Indonesia. P.T. Ichtiar Baru - Van Hoeve. Jakarta. 701 p.

Kardinan, A. 2003. Tanaman Pengendali Lalat Buah. Agromedia Pustaka. Jakarta. 49 p.

Khasanah, N., Nasir, B., \& Sulaeman. 2014. Persistensi Beberapa Ekstrak Tumbuhan Endemik Sulawesi Tengah Sebagai Insektisida Botani terhadap Spodoptera exigua (Lepidoptera: Noctuidae) EJournal Media Litbang Sulawesi Tengah 7: 31-37.
Kong, W.N., J. Li, R.J. Fan, S.C. Li, \& R.Y. Ma. 2014. Sex-Pheromone-Mediated Mating Disruption Technology for the Oriental Fruit Moth, Grapholita molesta (Busck) (Lepidoptera: Tortricidae): Overview and Prospects. Psyche 2014: 253924

Martono, E. 1997. Pengaruh Pemanfaatan Feromon Seks terhadap Serangga Hama. Jurnal Perlindungan Tanaman Indonesia 3: 106-114.

Mau, R.F.L. \& J.L.M. Kessing. 2007. Spodoptera exigua (Hubner).http://www.extento.hawaii.edu/kbase/ crop/type/spodopte.htm, modified 03/04/2017.

Nurjani \& Ramlan. 2008. Pengendalian Hama Spodoptera exigua Hubner untuk Meningkatkan Produktivitas Bawang Merah pada Lahan Sawah Tadah Hujan di Jeneponto, Sulawesi Selatan. Jurnal Pengkajian dan Pengembangan Teknologi Pertanian 11: 163-169.

Putrasamedja, S., W. Setiawati, L. Lukman, \& S. Hasyim. 2012. Penampilan Beberapa Klon Bawang Merah dan Hubungannya dengan Intensitas Serangan Organisme Pengganggu Tumbuhan. Jurnal Hortikultura 22: 349-359.

Reddy, G.V.P. \& K. Tangtrakulwanich. 2014. Potential Application of Pheromones in Monitoring, Mating Disruption, and Control of Click Beetles (Coleoptera: Elateridae). International Scholarly Research Notices 2014: 531061.

Santi, I.S., B. Sumaryo, \& F.X. Wagiman. 2008. Pengaruh Warna Perangkap Feromon terhadap Hasil Tangkapan Imago Oryctes rhinoceros di Perkebunan Kelapa Sawit. Jurnal Perlindungan Tanaman Indonesia 14: 76-79.

Sutarya, R. 1996. Hama Ulat Spodoptera exigua Hubn. pada Bawang Merah dan Strategi Pengendaliannya. Jurnal Litbang Pertanian 15: 41-46.

Wagiman, F.X., B. Triman, \& S. Astuti. 2003. Keefektifan Steinernema spp. terhadap Spodoptera exigua. Jurnal Perlindungan Tanaman Indonesia 9: 22-27.

Wyatt, T.D. 2010. Pheromones and Signature Mixtures: Defining Spesies Wide Signals and Variable Cues for Inividuality in Both Invertebrates and Vertebrates. Journal of Comparative Physiology 196: 685-700. 